\title{
JENIS DAN PERANAN TUMBUHAN AIR BAGI PERIKANAN DI PERAIRAN LEBAK LEBUNG
}

\author{
Marson") \\ Peneliti pada Balai Riset Perikanan Perairan Umum, Mariana-Palembang
}

\begin{abstract}
ABSTRAK
Perairan lebak lebung memegang peranan penting bagi perikanan air tawar di Indonesia dan juga di tropika lain. Perairan ini selain merupakan sumber protein hewani yang murah bagi penduduk sekitar tetapi juga merupakan sumber perikanan komersial. Kondisi pada musim hujan yang tergenangi dan musim kemarau yang surut menyebabkan daerah ini menjadi daerah bervegetasi, terdapat 37 jenis tumbuhan air di lebak lebung. Tumbuhan air baik secara langsung maupun tidak langsung dapat memberikan dampak yang positif terhadap populasi ikan. Peran dalam perikanan antara lain makanan bagi kita, tempat perlindungan. menetaskan dan menempelkan telur, tempat perlindungan bagi anak-anak ikan, sebagai aerator perairan, dan tempat berkembang berbagai biota perairan lain. Jenis tumbuhan air yang terapung seperti eceng gondok (Eichornia crassipes) dapat digunakan nelayan sebagai alat bantu menangkap udang galah. Tumbuhan air juga mempunyai dampak yang negatif apabila jumlah terlampau banyak. Tumbuhan air dapat mengakibatkan pendangkalan, menyumbat saluran air, bila menutupi perairan akan menghambat proses fotesintesis di dalam air, menghambat transportasi, dan bila malam hari akan menurunkan kadar oksigen di perairan.
\end{abstract}

KATA KUNCI: jenis, peran, tumbuhan air, lebak lebung

\section{PENDAHULUAN}

Perairan lebak lebung memegang peranan penting bagi perikanan air tawar di indonesia dan juga di tropika lain. Perairan ini bukan merupakan sumber protein hewani yang murah bagi penduduk sekitar tetapi juga merupakan sumber perikanan komersial.

Lebak lebung merupakan badan perairan yang air meluap menggenangi pada musim hujan dan menyurut pada musim kemarau. Tinggi muka air dipengaruhi perubahan musim dan lingkungan daerah aliran sungai. Perubahan tersebut berpengaruh terhadap keadaan biologi perikanan seperti produksi makanan alami, pertumbuhan, pemijahan, dan ruaya berbagai jenis ikan (Ondara, 1993).

Perairan lebak lebung banyak ditumbuhi tanaman kumpai (Graminae). Berdasarkan pada penelitian Utomo \& Ondara (1987), pada saat musim kemarau relatif lebih asam dari pada saat musim penghujan, di samping itu pada waktu kandungan $\mathrm{O}_{2}$ rendah dan $\mathrm{CO}_{2}$ tinggi ikan yang hidup di perairan lebak lebung pada umumnya golongan (ordo) Labyrintichi mempunyai alai pernapasan tambahan sehingga dapat hidup di perairan yang kadar $\mathrm{O}_{2}$ rendah dan agak asam $(\mathrm{pH}= \pm 5$ ). Kelompok ikan ini sering disebut kelompok ikan hitam (black fish), termasuk antara lain sepat siam (Trichogaster pectoralis), keli (Clarias spp.), gabus (Ophiocephalus striatus), betok (Anabas testudinius), selincah (Polyacanthus hasseltii), tembakang (Helostoma temminkil), dan lain-lain.

Di perairan lebak lebung banyak terdapat tumbuhan air. Tumbuhan air dalam keadaan dan waktu tertentu tidak dikehendaki, karena dianggap menimbulkan kerugian yang lebih besar dari manfaat yang ditimbulkan. Tumbuhan air adalah tumbuhan yang sebagian atau seluruh daur hidup berada di air dan mempunyai peranan sebagai produsen primer di perairan, jadi merupakan sumber makanan bagi konsumen primer atau biofag (antara lain ikan). Di samping itu, tumbuhan air juga membantu aerasi perairan melalui fotosintesis, mengatur aliran air, membersihkan aliran yang tercemar melalui proses sedementasi serta penyerapan partikel dan mineral. Tumbuhan air merupakan tempat pemijahan ikan, serangga, dan lain-lain. Sebagian jenis tumbuhan air juga memberikan sumber makanan langsung untuk manusia, misal umbi dari Eleocharis dulcis

Hampir semua perairan danau, waduk, rawa, dan lebak lebung di Indonesia ditumbuhi oleh tumbuhan air. Akan tetapi jumlah tumbuhan air yang terdapat di perairan-perairan umum berbeda-beda antara satu perairan dengan lain. Dari sudut ilmu lingkungan (ekologi), tumbuhan air merupakan salah satu komponen biotik dalam satu ekosistem perairan. Peranan dalam ekosistem perairan sangat tinggi.

Menurut Room (1984) gulma air adalah tumbuhan air yang dapat mengganggu penggunaan air oleh manusia. Soerjani (1982) mendefinisikan tumbuhan air sebagai gulma air yang dalam keadaan dan waktu tertentu tidak dikehendaki, karena dianggap menimbulkan kerugian yang melebihi peranan yang menguntungkan

Berdasarkan pada sifat hidupn, macam tumbuhan air yaitu tumbuhan air tingkat tinggi tumbuh di tepian (marjinal plant), tumbuhan terapung (free floating plant), tumbuhan mencuat (emersed plant), bawah air (submersed plant), tumbuhan terapung berakar di dasar (roted floating plant), dan tumbuhan pulau terapung (floating island plant) 
Salah satu peran tumbuhan air adalah digunakan oleh kelompok ikan non predator sebagai tempat perlindungan dari kejaran ikan pemangsa (predator).

Dalam tulisan ini akan dibahas jenis-jenis tumbuhan air, permasalahan, dan manfaat bagi populasi ikan terhadap tumbuhan air yang ada di lebak lebung.

\section{JENIS TUMBUHAN AIR}

Untuk memperoleh gambaran umum, urutan sepuluh gulma air penting di Indonesia adalah seperti terlihat pada Tabel 1.

Jenis tumbuhan air yang umum terdapat di setiap perairan lebak lebung, secara umum dikelompokkan menjadi 3 yaitu tumbuhan air mencuat, tenggelam, dan terapung. Tumbuhan air mencuat adalah tumbuhan air yang muncul di atas permukaan air dengan batang-batang serta akar-akar melekat di dasar perairan contoh. Scirpus grosus. Sedangkan tumbuhan air tenggelam adalah tumbuhan air dengan keseluruhan bagian di dalam air, akar melekat pada dasar perairan, contoh Hidrila, tumbuhan air tenggelam yang akar terlepas dari tanah contoh Utrucularia sp. Adapun contoh tumbuhan air yang mengapung bebas yaitu eceng gondok (Eichornia crassipes), tumbuhan air mengapung daun muncul di permukaan air tapi akar melekat di dasar perairan contoh Nympea sp. Berdasarkan pada hasil pengamatan Samuel \& Ondara (1986) terdapat 37 jenis tumbuhan air yang hidup di lubuk lampam, (Sumatera Selatan). Tabel 2.

\section{MANFAAT TUMBUHAN AIR}

Manfaat tumbuhan air antara lain sebagai aerator perairan melalui proses fotosintesis. Pada keadaan air besar sebagian dari tumbuhan air di lahan tebak kumpai dan rawang terapung mengerombol seperti pulau. Tumbuhan air yang terapung tersebut dapat berfungsi sebagai pelindung bagi ikan dari serangan ikan buas, dan atau sebagai tempat menempelkan telur. Tumbuhan air jenis Polygonum (sebakat) dan Echinochloa spp. (kumpai) merupakan tumbuhan air yang disenangi oleh ikan tembakang (Helostoma temminskii) sebagai tempat pemijahan (mengempas) Jenis tumbuhan air yang terapung seperti eceng gondok (Eichhornia crassipes) dapat digunakan nelayan untuk menangkap udang galah di Batanghari yang disebut dengan istilah ngapung. Pada saat air menjelang surut, sebagian dari lahan perairan menjadi kering dan sebagian lainnya tergenang air (lebung-lebung dan alur-alur anak sungai). Pada keadaan tersebut sebagian jenis ikan lebak (kelompok ikan hitam) pada umumnya mencari tempat-tempat yang berair. Kelompok ikan hitam ini menurut kebiasaan hidup jarang melakukan migrasi ke sungai utama yang didominasi oleh ikan putih. (Samuel et al. 1992).

Berdasarkan pada pengamatan pada saat air menjelang surut jenis ikan hitam berusaha meyelamatkan diri dengan mencari tempat-tempat yang ada air. Pada saat berkumpul itu kesempatan bagi ikan predator untuk memangsa ikan lain. Namun, pada saat ini tumbuhan air digunakan oleh kelompok ikan dari berbagai jenis untuk tempat perlindungan dari kejaran ikan pemangsa (predator)

Tumbuhan cetot (Eichhornia crassipes) digunakan oleh nelayan sebagai alat bantu untuk menangkap udang di sungai dengan cara menghanyutkan cetot ke sungai dengan sendiri udang akan bergantungan di bawah cetot. Kumpai bulu dan kumpai tembago (Echinochloa spp.), yang paling dominan di lebak kumpai, merupakan tempat berkumpul berbagai serangga air, dan daerah tersebut menjadi tempat yang baik bagi ikan-ikan pemakan serangga untuk mencari makanan

Pada musim kemarau, semua perairan menjadi kering. kecuali sungai utama, lebung-lebung, dan aluralur anak sungai yang dalam. Pada keadaan ini sebagian aktivitas penangkapan ikan di lahan lebak kumpai yang dapat dilakukan kelompok nelayan berkarang berhenti dan mereka mulai terpusat pada aktivitas penangkapan di sungai dan di lebung Beberapa tumbuhan air seperti jenis Phragmittes spp.

Tabel 1. Sepuluh tumbuhan air penting di Indonesia

\begin{tabular}{|c|c|c|c|}
\hline No. & $\$ \% 118$ & Nama umum & Fanill \\
\hline 1. & Eichhornia crassipes & Eceng gondok & Potenderiaceae \\
\hline 2. & Salvinia molesta & Janji & Salviniaceae \\
\hline 3. & Hydrilla verticillata & Ganggang & Hydrocharitaceae \\
\hline 4. & Scirpus grossus & Wlingen & Cyperacea \\
\hline 5. & Najas indica & Ganggang & Najadaceae \\
\hline 6. & Ceratophyllum demersum & Ganggang & Ceratophyllaceae \\
\hline 7. & Nelumbo nucifera & Teratai & $\mathrm{N}$ elumbonacae \\
\hline 8. & Panicum repens & Lempuyangan & Poaceae \\
\hline 9. & Potamageton & & Potamogetonaceae \\
\hline 10. & Mimosa pigra & Klampis air & Mimosaceae \\
\hline
\end{tabular}


Tabel 2. Jenis tumbuhan air yang terdapat di perairan lubuk lampam, Sumatera Selatan

\begin{tabular}{|c|c|c|c|}
\hline \multirow{2}{*}{ Nor } & \multicolumn{2}{|c|}{ Jengis } & \multirow{2}{*}{ Famil } \\
\hline & , & - & \\
\hline 1. & Azolla pinnata & Kiambang & Salviniaceae \\
\hline 2. & Ceratophyllum demersum & Reamun & Ceratophyllaceae \\
\hline 3. & Cyperus & Memerung & Cyperaceae \\
\hline 4. & Echinochloa crusgalli & Kumpai Tembago & Poaceae \\
\hline 5. & Echinochloa stagnina & Kumpai Bulu & Poaceae \\
\hline 6. & Eichhornia crassipes & Cetot & Pontederiaceae \\
\hline 7. & Eleocharis spp. & Menerung & Cyperaceae \\
\hline 8. & Equisetum spp. & Purun & Equisetaceae \\
\hline 9. & Hydril/a verticil/ala & Reamun & Hydrocharitaceae \\
\hline 10. & Hymenachne amplexicaulis & Kumpai Gajah & Poaceae \\
\hline 11. & Ipomoea fistolusa & Kangkungan & Convolvulaceae \\
\hline 12. & Leersia hexandra & Kumpai Kawat & Poaceae \\
\hline 13. & Lemna perpusil/a & Mata Lele & Lemnaceae \\
\hline 14. & Limnophilil/a heterophylla & Reamun & Scrophulariaceae \\
\hline 15. & Ludwigia adscendens & Sabut Lintah & Onagraceae \\
\hline 16. & Ludwigia octavalvis & Sabut Lintah & Onagraceae \\
\hline 17. & Ludwigia peruviana & Sabut Lintah & Onagraceae \\
\hline 18. & Mimosa pigra & Kayu Duri & Mimosaceae \\
\hline 19. & Monochoria hastate & Keladi Air & Pontoderiaceae \\
\hline 20. & Myriophyllum brasiliense & Reamun & Haloragaceae \\
\hline 21. & Najas graminae & Reamun & Najadaceae \\
\hline 22. & Najas indica & Reamun & Najadaceae \\
\hline 23. & Nymphaea nauchali & Mentalam & N ymphaeaceae \\
\hline 24. & Nyimphoides indica & Mentalam & Gentianaceae \\
\hline 25. & Oryza sativa VAR & Padi Burung & Poaceae \\
\hline 26. & Ottelia alismoides & Wewean & Hydrocharnaceae \\
\hline 27. & Phragmittes spp. & Teriti & Poaceae \\
\hline 28. & Pistia stratiotes & Kayu Apu & Araceae \\
\hline 29. & Polygonum barbatum & Sebakat & Polygonaceae \\
\hline 30. & Polygonum pulchrum & - & Polygonaceae \\
\hline 31. & Sacciolepis interrupta & Kumpai Lengoh & Ponaceae \\
\hline 32. & Salvina cucullate & Kiambang & Salviniaceae \\
\hline 33. & Salvina molesta & Kiambang & Salviniaceae \\
\hline 34. & Salvena natans & Kiambang & Salviniaceae \\
\hline 35. & Scirpus spp. & Menerung & Cyperaceae \\
\hline 36. & Spirodella polyrhiza & Matalele & Lemmaceae \\
\hline 37. & Typha angustifolia & Perumpung & Typhaceae \\
\hline
\end{tabular}

Sumber/Sources: Samuel \& Ondara, 1986

yang telah tua batangnya digunakan untuk melakukan penangkapan ikan di sungai atau di lebung-lebung sebagai pemikat ikan. Jenis tumbuhan lain yang bermanfaat adalah Eleocharis spp, digunakan oleh nelayan untuk bahan kemasan garam dan ikan asin.

Kegiatan lain yang tidak kalah menarik adalah kebiasaan nelayan di musim kemarau membakar tumbuh-tumbuhan air yang telah kering seperti kumpai (Graminae atau Poaceae) dan kayu duri (Mimosaceae). Pembakaran tumbuhan air pada musim kemarau dapat memberikan dampak yang positif pada tanah yang ditumbuhi. Kemudian pada saat musim penghujan air banjir sehingga daerah rawang dan lebak kumpai akan kembali digenangi air. Mengingat tanah dasar perairan yang baru tergenang tersebut telah menjadi subur akibat pembakaran pada saat musim kemarau, maka dengan sendiri perairan yang bersangkutan akan menjadi subur. Berbagai jenis tumbuhan air mulai tumbuh dan berkembang kembali, demikian pula hal dengan ferifiton fitoplankton.

Berbagai jenis ikan pada keadaan air menjelang banjir mulai kembali melakukan aktivitas kehidupan dengan susunan yang lebih baik dari keadaan sebelumnya. Bagi anak-anak ikan pada musim ini merupakan peluang yang baik dalam memanfaatkan fitoplankton dan ferifiton serta tumbuh-tumbuhan air yang baru tumbuh sebagai makanan.

\section{PERMASALAHAN}

Di Indonesia permasalahan tumbuhan air adalah pertumbuhan yang sangat pesat pada beberapa perairan seperti Danau Kerinci, Rawa Pening. Waduk Saguling, dan Bendung Curug. Selain itu, 
berkembang pula bermacam jenis-jenis tumbuhan air lain seperti di lebak lebung, saluran irigasi, dan sungai. Tumbuhan air yang melimpah akan menimbulkan dampak kurang baik bagi perikanan, karena tumbuhan air yang melimpah akan mempercepat suatu pendangkalan perairan dan memperbesar evapotranspirasi. Penurunan hasil perikanan akibat rendah kadar oksigen terlarut di bawah permukaan air yang tertutup tumbuhan air, serta tidak ada proses difusi antara air dengan udara.

Kerugian yang ditimbulkan oleh tumbuhan air yang tergabung gulma lebih besar dibandingkan dengan peranan atau manfaat bagi manusia. Bagaimana dan seberapa guima air menimbulkan kerugian sangat tergantung kepada tujuan pemanfaatan perairan itu sendiri (Holm et al., 1969). Ada kemungkinan bahwa tumbuhan air merugikan karena menguragi volume air yang disimpan di waduk atau danau karena evapotranspirasi serta keberadaan yang mendesak volume simpan air, mengganggu aliran air, baik dari saluran pengairan maupun saluran drinase. Gulma air juga dapat mengganggu transportasi dengan perahu serta memperbesar permasalahan hama pertanian maupun vektor penyakit manusia.

Gangguan tumbuhan air terhadap perikanan benar tergantung kepada kenyataan seberapa jauh keseimbangan antara kesuburan air, produksi primer, dan produksi ikan mengalami ganguan. Produksi primer suatu perairan akan terbatas menurut sumber kesuburan yang diperoleh. Kalau produksi primer yang terbatas itu kemudian mengumpul secara tidak berimbang dalam bentuk gulma air, maka produksi primer dalam bentuk lain seperti plankton dan algae akan berkurang. Oleh karena itu, produksi ikan pemakan plankton seperti silver carp (Hypophthalmichtys molitrix) dan pemakan algae seperti mujair (Saotherodon mossambicus), serta ikan tambakan (Hilostoma temmincld) juga berkurang.

\section{KESIMPULAN}

Dari uraian tentang masalah dan pemanfaatan tumbuhan air di perairan lebak lebung tersebut di atas, dapat disimpulkan bahwa dalam keadaan tertentu. di mana kelimpahan air dalam batas tertentu, peranan tumbuh-tumbuhan air bagi sumber daya perikanan tidak dapat diabaikan bagi kelestarian lingkungan dan kestabilan produksi ikan dari tahun ke tahun

Beberapa jenis tumbuhan air baik secara langsung maupun tidak langsung dapat memberikan dampak yang positif terhadap populasi ikan. Peranan dalam perikanan dapat berbagai macam antara lain tumbuhan air dapat merupakan makanan bagi ikan, sebagai tempat perlindungan, tempat menetaskan dan menempelkan telur, tempat perlindungan yang baik bagi anak-anak ikan, sebagai aerator perairan. serta tempat berkembang berbagai biota perairan lain. Jenis tumbuhan air yang terapung seperti eceng gondok (Eichhornia crassipes) dapat digunakan nelayan sebagai alat bantu menangkap udang galah.

Tumbuhan air juga mempunyai dampak yang negatif apabila jumlah terlampau banyak. Tumbuhan air dapat mengakibatkan pendangkalan, menyumbat saluran air, bila menutupi perairan akan menghambat proses fotosintesis di dalam air, menghambat transportasi, bila malam hari akan menurunkan kadar oksigen di perairan.

Untuk itu perlu ada pengontrolan jumlah tumbuhan air di perairan agar tidak terlampau banyak, apalagi sampai dengan menutupi perairan.

\section{DAFTAR PUSTAKA}

Holm, L. G. Weldon, L. W., \& Blackburn, R. D. 1969 Aquatic Weeds Science 1966. 699-709.

Ondara. 1993. Pemanfaatan dan pengelolaan perikanan perairan lebak lebung. Temu Karya IImiah Perikanan Perairan Umum. Prosiding Pengkajian Potensi dari Prospek Pengembangan Perairan Umum Sumatera Bagian Selatan. Hal: 89-105.

Room, P. M. 1984. Biological control of aquatic weeds. Lectore note in Tyraining Corse on Aquatic Weeds. March 12-April 1984. Biostrop. Bogor. Indonesia. 12 hal.

Samuel \& Ondara. 1986. Kemelimpahan dan penyebaran tumbuhan air serta hubungannya dengan sumber daya perikanan di perairan lubuk lampam interen. Sub Balai Penelitian Perikanan Air Tawar. Palembang. 18 hal.

Samuel, Yosmaniar, \& A. S. Sarnita. 1992. Peranan tumbuh-tumbuhan air di perairan lebak lebung dalam perikanan. Temu Karya Ilmiah Perikanan Perairan Umum. Prosiding Pengkajian Potensi dan Prospek Pengembangan Perairan Umum Sumatera Bagian Selatan. Hal: 135-139.

Soerjani, M. 1978. Aquatic weed problems and thier control. Philippine Journal of Weed Science. 5: 44 .53

Soerjani, M. 1982. Masalah gulma air di Indonesia. Prosiding Seminar Perikanan Perairan Umum Indonesia. Hal: 33-41.

Utomo, A. D. \& Ondara. 1987. Pendugaan potensi ikan di perairan lebak lubuk lampam. Buletin Penelitian Perikanan Darat. Vol.6 No.1 Juni 1987. Bogor. Indonesia. 